EPJ Web of Conferences 79, 04003 (2014)

DOI: $10.1051 /$ epjconf/20147904003

(C) Owned by the authors, published by EDP Sciences, 2014

\title{
How to engage end-users in smart energy behaviour?
}

\author{
Pieter Valkering ${ }^{1, a}$, Erik Laes ${ }^{1}$, Kris Kessels ${ }^{1}$, Matthijs Uyterlinde ${ }^{2}$ and Koen Straver $^{2}$ \\ ${ }^{1}$ VITO, Boeretang 200, 2400 Mol, Belgium \\ ${ }^{2}$ ECN, Postbus 1, 1755 ZG Petten, The Netherlands
}

\begin{abstract}
End users will play a crucial role in up-coming smart grids that aim to link endusers and energy providers in a better balanced and more efficient electricity system. Within this context, this paper aims to deliver a coherent view on current good practice in end-user engagement in smart grid projects. It draws from a recent review of theoretical insights from sustainable consumption behaviour, social marketing and innovation systems and empirical insights from recent smart grid projects to create an inventory of common motivators, enablers and barriers of behavioural change, and the end-user engagement principles that can be derived from that. We conclude with identifying current research challenges as input for a research agenda on end-user engagement in smart grids.
\end{abstract}

\section{Introduction}

End-users will play a crucial role in up-coming smart grids that aim to link end-users and energy providers in a better balanced and more efficient electricity system. However, although a variety of insights are available, a consistent and integrated view on how to engage end-users in smart grid projects to promote smart energy behaviour is lacking. Therefore, a literature review [1] was conducted to establish a clear view on the state-of-the-art of end-user engagement in smart grid projects from both a theoretical and from an empirical perspective. This paper summarizes key findings from the literature review in terms of the reported enablers and barriers for engaging end-users in smart energy behaviour (Sect. 3), recommendations or "success factors" for end-user engagement (Sect. 4), and a number of key challenges for future research and development (Sect. 5). For details of the literature review, the reader is referred to the full report [1].

\section{Scope of the literature review}

The literature review draws from various strands, broadly distinguishing a theoretical and empirical perspective.

The theoretical perspective includes relevant theoretical models/frameworks for understanding smart energy behaviour from a psychological, economic, sociological, innovation, transitions and marketing perspective. From these models and frameworks, the review extracts key insights on typical drivers of

\footnotetext{
${ }^{a}$ Corresponding author: valkering@vito.be
}

This is an Open Access article distributed under the terms of the Creative Commons Attribution License 4.0, which permits unrestricted use, distribution, and reproduction in any medium, provided the original work is properly cited. 


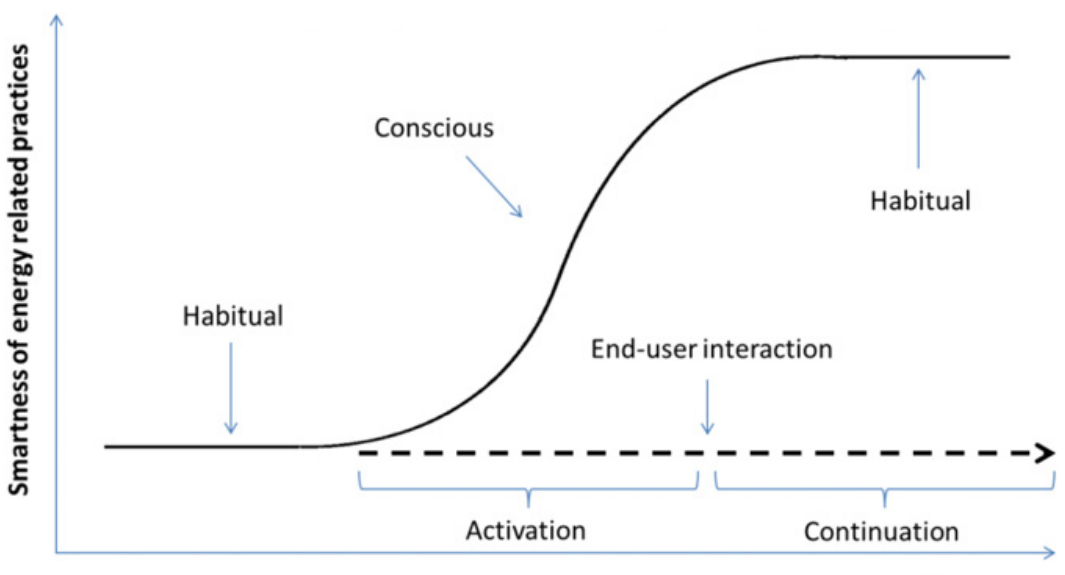

Time

Figure 1. A stylised interpretation of the process of end-user-interaction distinguishing an "activation" and "continuation" phase.

end-user behaviour, the segmentation of different end-user types, and how to actively engage end-users in projects like the ones in the area of smart grid.

The empirical perspective includes various evaluation reports and meta-reviews of experiences with smart grid projects. From this literature, this report synthesises current views on "what works" in enduser engagement concerning tariff structures and incentives, feedback, communication and engagement strategies, and privacy and security issues. Also, it draws from literature on new smart grid market models - describing innovative ways of how different market players and end-users can interact under a smart grid framework - and it reviews experience with uptake of innovations in other related sectors like telecom.

\section{Enablers and barriers for engaging in smart energy behaviour}

Smart energy behaviour typically entails energy efficiency (using no more energy than is needed), flexibility (e.g. shifting energy demand to times of relative energy surplus) and sustainable energy generation (for example through photovoltaic cells or other means). What do the theoretical and empirical insights tell us about the enablers and barriers of such smart energy behaviour? We first note that smart energy behaviour includes behaviours at different levels of consciousness, ranging from habitual to conscious and one-shot behaviour [2]. Energy related practices as such - like washing, cooking, heating etc. - can typically be considered habitual. However, behaviours towards a change of practices - like deciding whether to engage in a smart grid project and / or to buy smart appliances are rather conscious or even one-shot.

Figure 1 presents this view in a highly stylized manner. The process of end-user engagement in smart grid programs and their consequent interaction with new technologies, feedback and pricing schemes (i.e. the "end-user interaction scheme") is interpreted as a process of practice change towards a higher level of "smartness". At the start of the process, it is assumed that end-users carry out their energy related practices in a rather habitual manner. As end-users become engaged in a smart grid program, they are stimulated towards more conscious decision-making. This phase can be considered rather "disruptive", as existing practices need to be reconsidered and redefined. In this "activation phase", end-user interaction is targeted typically at achieving active end-user participation and an explicit consideration of old and new practices. As new practices are adopted, behaviour becomes again more 


\section{$3^{\text {rd }}$ European Energy Conference}

Table 1. Possible enablers and barriers of end-user engagement in smart grid projects listed in the literature.

\begin{tabular}{|c|c|c|}
\hline Category & Enablers & Barriers \\
\hline Comfort & Comfort (gain) & Comfort (loss) \\
\hline Control & $\begin{array}{l}\text { More energy independence ("energy } \\
\text { autarky") } \\
\text { Extended possibilities to participate in the } \\
\text { electricity market } \\
\text { More advanced control of appliances, e.g. } \\
\text { using mobile devices. }\end{array}$ & Loss of control over appliances \\
\hline Environment & Environmental benefits & \\
\hline Finance & $\begin{array}{l}\text { Financial or in kind incentives } \\
\text { Reduction of the energy bill }\end{array}$ & $\begin{array}{l}\text { Investment costs } \\
\text { Increased energy bill }\end{array}$ \\
\hline $\begin{array}{l}\text { Knowledge \& } \\
\text { Information }\end{array}$ & $\begin{array}{l}\text { More transparent and frequent billing } \\
\text { Detailed knowledge about electricity use }\end{array}$ & $\begin{array}{l}\text { Unclear information about the smart grid } \\
\text { program (technologies / incentives / pricing } \\
\text { schemes) } \\
\text { Lack of competences, e.g. to deal with new } \\
\text { technologies or to negotiate with energy } \\
\text { suppliers } \\
\text { Lack of awareness about the concept 'smart } \\
\text { grid' and its potential gains } \\
\text { Perceived risks, e.g. adverse health effects }\end{array}$ \\
\hline Security & Improved reliability of energy supply & Privacy and security concerns \\
\hline Social process & $\begin{array}{l}\text { Role models } \\
\text { Customer testimonial } \\
\text { Community feelings } \\
\text { Competition } \\
\text { Fun }\end{array}$ & $\begin{array}{l}\text { Free rider effects } \\
\text { Job losses }\end{array}$ \\
\hline
\end{tabular}

habitual. End-user interaction is then more aimed at supporting and reinforcing the new energy practices ("continuation phase").

Here, we focus on reported key enablers and barriers that may be important in the "activation" and "continuation" phases of end-user interaction. Literature reports on a variety of factors end-users consider when deciding whether to engage in (and continue with) a smart grid program. These factors can be classified as either enablers (reasons why end-users may be tempted to engage) or barriers (reasons why they would not). Table 1 presents an overview of the various possible enablers and barriers listed in the literature. They are grouped under the categories (in alphabetical order) comfort, control, environment, finance, knowledge \& information, security, and social process.

Interestingly, for most categories both enablers and barriers can be identified:

- Comfort: Possible loss of comfort is an often mentioned barrier, see e.g. [3]. Smart grid technology may also increase levels of comfort, also mentioned as a potential enabler as such.

- Control: An often mentioned barrier to engagement is the perceived loss of control over appliances, as automated control algorithms "take over" appliances [4, 5]. Smart grid technology, however, may also extend the possibilities for control, for example, through more advanced possibilities for controlling appliances (e.g. using mobile devices), extended possibilities to participate in the electricity market (e.g. [6]), and possibilities for becoming more energy independent ("energy autarky").

- Environment: The environmental benefits of smart grid development - reducing greenhouse gas emissions by integrating renewables into the grid - is a reported key benefit end-users may strongly care about (e.g. [7]).

- Finance: It is clear that financial or "in kind" incentives and the expectation of a reduced energy bill may be clear enablers for engaging in smart grid programs (e.g. [3, 4, 6, 7]). On the other hand, engagement may also require investment costs for smart appliances, and may also lead a higher energy bill for end-users requiring electricity at peak times. 
Table 2. Success factors for end-user engagement described in the literature for the activation phase.

\begin{tabular}{|l|l|l|}
\hline Success factor & Empirical findings & Theoretical concepts \\
\hline $\begin{array}{l}\text { Provide added value } \\
\text { value }\end{array}$ & $\begin{array}{l}\text { Attractive financial incentives } \\
\text { Comfort gains rather than losses } \\
\text { New information services } \\
\text { Data privacy and security } \\
\text { Allow automatic procedure overruling }\end{array}$ & $\begin{array}{l}\text { Product, Price (4P) } \\
\text { Exchange (Social Marketing) } \\
\text { Encourage (4E) } \\
\text { Rational appeals [19] }\end{array}$ \\
\hline $\begin{array}{l}\text { Understand the } \\
\text { end-user }\end{array}$ & $\begin{array}{l}\text { Apply segmentation } \\
\text { Consider broad scope of behavioural } \\
\text { determinants } \\
\text { Special focus low income / vulnerable end- } \\
\text { users } \\
\text { Understand social practices, daily routines } \\
\text { and social context }\end{array}$ & $\begin{array}{l}\text { Customer orientation, Theory, Insight, } \\
\text { Segmentation (Social Marketing) }\end{array}$ \\
\hline $\begin{array}{l}\text { Educate the } \\
\text { end-user }\end{array}$ & $\begin{array}{l}\text { Consider consumer (non-)ability to deal } \\
\text { with new technology } \\
\text { Educate end-users before deployment } \\
\text { Provide training }\end{array}$ & $\begin{array}{l}\text { Enable (4E) } \\
\text { Transparent and understandable information } \\
\text { \& training [19] }\end{array}$ \\
\hline $\begin{array}{l}\text { Create } \\
\text { commitment \& } \\
\text { appeal }\end{array}$ & $\begin{array}{l}\text { Establish trust in the whole process } \\
\text { Early end-users involvement } \\
\text { Role models } \\
\text { Customer testimonials } \\
\text { Deal with free-rider effects } \\
\text { Effective marketing and outreach } \\
\text { Emphasising key benefits } \\
\text { Creating lifestyles around products }\end{array}$ & $\begin{array}{l}\text { Engage (4E) } \\
\text { Build trust and confidence, Emotional } \\
\text { appeals [19] } \\
\text { Reciprocity, Commitment, Social Proof, } \\
\text { Liking, Authority, Scarcity (Cialdini) } \\
\text { Promotion (4P) } \\
\text { Competition (Social Marketing) } \\
\text { AIDA model }\end{array}$ \\
\hline
\end{tabular}

- Knowledge \& information: More transparent and frequent billing information and detailed knowledge about energy use by different appliances are considered a key benefit for end-users engaging in a smart grid program (e.g. [6]). Yet, the lack of adequate knowledge and information provision about the smart grid program may act as a barrier (e.g. [8]). Additional barriers in this category are lack of competences to deal with new technologies or to negotiate with energy suppliers (e.g. [8]), a lack of awareness about the concept "smart grid" and its potential gains, and perceived risks like the (supposedly) adverse health effects of wireless signals (e.g. [5, 7]).

- Security: A typical security issue is improved reliability, often mentioned as an important advantage (e.g. [6, 7]). On the other hand, privacy and security concerns are reported as potential barriers (e.g. [4, 7]).

- Social process: The positive stimuli social processes may provide are mostly reported as enablers of end-user engagement. This concerns, for example, the stimulating effect of role models [8] and customer testimonials [7], and the "community feelings" and sense of competition smart grid programs may appeal to [4], basically making participation "fun". To some extent, social values are also reported as barriers, for example through "free rider effects" [6] (creation of a sense of unfairness, because non-participants of the smart grid also benefit from peak shaving) or job losses [7] (as meter readers will no longer be needed) end-users don't want to be responsible for.

\section{Recommendations for successful end-user engagement}

Given the insights in enablers and barriers, in what ways can smart energy behaviour be facilitated? To address this question, we classified the various recommendations from literature into a set of key success factors supported both by empirical findings and established theoretical insight. We thereby distinguish success factors that are applicable mostly to the activation phase (Table 2) and ones that are mostly applicable to the continuation phase (Table 3). The column "empirical findings" in these tables 


\section{$3^{\text {rd }}$ European Energy Conference}

Table 3. Success factors for end-user engagement described in the literature for the continuation phase.

\begin{tabular}{|c|c|c|}
\hline Success factor & Empirical findings & Theoretical concepts \\
\hline $\begin{array}{l}\text { Effective feed- } \\
\text { back, pricing \& } \\
\text { communication }\end{array}$ & $\begin{array}{l}\text { Consider direct and indirect feedback } \\
\text { interactive and disaggregated feedback and } \\
\text { linking feedback directly to advice on } \\
\text { action. } \\
\text { Consider attributes like the rationale of the } \\
\text { scheme, the number of time blocks used, } \\
\text { the price update frequency etc. } \\
\text { Ensure a continuous information flow. } \\
\text { Linking feedback, pricing and } \\
\text { communication strategies }\end{array}$ & $\begin{array}{l}\text { Communications theory: take into account, } \\
\text { sender, target group, aim, message, timing } \\
\text { communication channels }\end{array}$ \\
\hline $\begin{array}{l}\text { Variety of } \\
\text { intervention } \\
\text { methods }\end{array}$ & $\begin{array}{l}\text { Variety of feedback information and } \\
\text { channels } \\
\text { Variety of tailored dynamic pricing } \\
\text { schemes }\end{array}$ & \\
\hline Ease of use & $\begin{array}{l}\text { User-friendly, intuitive designs } \\
\text { Pro-active support and service (e.g. using } \\
\text { social media) }\end{array}$ & $\begin{array}{l}\text { Enable (4E) } \\
\text { Provide support and services [19] }\end{array}$ \\
\hline $\begin{array}{l}\text { Social } \\
\text { comparison }\end{array}$ & $\begin{array}{l}\text { Individual energy saving targets } \\
\text { Appeal to the competitive nature of people } \\
\text { Social feedback }\end{array}$ & \\
\hline $\begin{array}{l}\text { Reflection \& } \\
\text { learning }\end{array}$ & $\begin{array}{l}\text { Elicit and follow-up end-users' } \\
\text { expectations } \\
\text { Monitoring and evaluation cycles } \\
\text { Position initiatives within a wider } \\
\text { programme with clear objectives } \\
\text { Co-creation of knowledge }\end{array}$ & $\begin{array}{l}\text { Societal transitions [20] } \\
\text { Social Marketing }\end{array}$ \\
\hline
\end{tabular}

contains illustrative examples for the corresponding success factor drawn from the empirical strand of literature. The column "theoretical concepts" provides corresponding concepts from the theoretical strand, such as reflected in key (social) marketing models like the 4P's marketing mix [9] (product, price, promotion, place), the AIDA model [10] (attention interest, desire, action), Cialdini's principles of influence [11] (reciprocity, commitment, social proof, liking, authority, scarcity), Defra's 4E model [12] (enable, encourage, engage, exemplify), and Social Marketing [13].

For the activation phase, we arrive at the following key success factors:

- Provide added value: This corresponds broadly with providing clear added value on the various categories of enablers, while relieving barriers as much as possible. This includes, for example, applying attractive financial incentives, ensure comfort gains rather than losses, providing new information services, ensuring data privacy and security, and include possibilities to overrule automatic procedures while offering new forms of end-user control.

- Understand end-users: Different target groups may be susceptible to very different enablers and barriers. The challenge is thus to understand which ones are of particular relevance, and to base engagement strategies on that (e.g. [4, 6-8]).

- Educate end-users: Relieving possible knowledge \& information barriers will involve some form of education as programs need to take into account consumer (non-)ability to deal with new technology (e.g. [7, 8, 14-18]).

- Create commitment \& appeal: This involves taking full advantage of social processes as important enablers. This includes ensuring trust in the whole smart grid process, involving end-users at early project stages, involving role models, believable customer testimonials, and dealing with possible free-rider effects. Creating commitment $\&$ appeal also requires effective marketing and outreach 
to create a "desire" for new products, for example by emphasising key benefits and creating new lifestyles around products. See e.g. [6-8].

In the continuation phase, the following factors appear particularly relevant:

- Effective feed-back, pricing \& communication: A lot is known about which factors need to be considered when designing effective feedback (system communication) and pricing schemes. Regarding project communication, it is particularly important to ensure a continuous information flow to maintain high engagement levels. Moreover, it is considered promising to link dynamic pricing, convincing feedback mechanisms and communication strategies to achieve an optimal response.

- Variety of intervention methods: Although understanding the end-user is key, there are limitations on the extent to which "tailor made solutions" can be offered, especially for a heterogeneous target group. Several studies therefore also stress the need for adopting a variety of intervention methods and techniques to serve different user types. See e.g. [16, 18].

- Ease of use: User-friendly, intuitive designs are important to minimize effort needed for operating new devices and schemes (i.e. to minimize knowledge \& information barriers perceived by endusers). Ease of use also includes adequate and pro-active support and service. See e.g. [7, 17, 19].

- Social comparison: It is generally considered stimulating to allow end-users to compare their (new) energy behaviours to peers. Besides setting individual energy-saving targets, this thus involves comparing those targets (and their fulfilment) to others. See e.g. [4, 8, 16].

- Reflection \& learning: Smart grid innovations can be considered "complex", involving many connections to other domains and scale levels and significant uncertainties on technical, social and other dimensions. Reflection and learning is therefore needed throughout the process. This may include eliciting and evaluating end-users' expectations, incorporating monitoring and evaluation cycles, letting initiatives explicitly be part of a wider programme with clear objectives, and creating arenas in which end-users, suppliers, designers and other actors collaborate and co-create knowledge in the further development of the smart grid. See e.g. [8, 13, 20].

\section{Key challenges for (research on) end-user engagement in smart grids}

Finally, we formulate key challenges for (research on) end-user engagement in smart grid projects reflecting current gaps in knowledge. Looking back on Fig. 1, the overall challenge may be formulated as: "how to contribute to smarter energy behaviour"? In other words, how to break "old" routines and practices of energy use, and support the development and new "smarter" ones? Within this scope, the following key challenges are defined:

A $1^{\text {st }}$ challenge relates to identifying and targeting specific end-user groups. Although the overall scope of potential enablers, barriers and success factors for end-user engagement is relatively clear (see Table 1, Table 2, and Table 3), it is as yet largely unclear how these should be related to the different type of end-users that may be targeted. End-user segmentation is one of the approaches that may be further developed in this respect. The challenge is thus to find instruments or approaches that contribute to achieving better understanding of the enablers and barriers of target groups and the type of end-user interaction scheme best suited to them.

A $2^{\text {nd }}$ challenge relates to the added value of smart grid related products from the perspective of the end-user. The current energy system in Western Europe operates with few flaws. End-users are used to being able to use electricity whenever they see fit. The risk with smart grid projects is being perceived as "demanding" a lot from customers (in return to reduction of price), rather than as a project that makes an interesting offer (for which end-users would be even willing to pay). In that sense, smart grid technology is a challenging technology to "sell". The challenge is thus to find innovative products and services that provide clear added value to end-users, while contributing to fostering smart energy behaviour. 
Further challenges involve a better empirically grounded understanding of the effect of respectively feedback (challenge 3) and dynamic pricing (challenge 4) on energy use, peak clipping and other enduser response. Notably, further research is needed to assess the effect of combinations of approaches and to identify critical success factors. The challenge is thus to understand both which (monetary or non-monetary) incentives and pricing schemes, as well as feedback information and feedback channels contribute to fostering smart energy behaviour.

A $5^{\text {th }}$ key challenge relates to the use of communication channels, information and marketing techniques. Although a number of general recommendations on communication and information provision can be given, empirical evidence on the effect of communication and information on smart energy behaviour remains weak. Moreover, although the field of marketing has shown the added value of applying marketing techniques, actual use of such techniques in smart grid projects remains weak. The challenge is thus to better understand which communication channels, information and marketing techniques contribute to recruitment and engagement of end-users in smart energy projects.

A $6^{\text {th }}$ key challenge relates to the cooperation between stakeholders. Current smart grid projects may include various actors other than the traditional energy players. It is as yet unclear how this involvement of non-energy players may influences end-user engagement. The challenges is thus to understand to what extent involvement of non-energy stakeholders contributes to end-user engagement and smart energy behaviour.

A $7^{\text {th }}$ key challenge relates to the end-users as initiators of projects. Whereas the literature describes a variety of results on end-user involvement, relatively little is reported on "bottom-up" projects in which end-users are initiators and "owners" of the project. Here, combining smart grid research with research on smart cities seems promising, as the latter does tend to place the end-user in a more central role. The challenge is thus to find instruments or approaches that contribute to facilitating end-user empowerment.

An $8^{\text {th }}$ key challenge relates to the new market structures and the role of end-users in those structures. Although a number of projects have addressed this issue, further testing is needed. Key questions include, for example, how legislation and regulation can better support smart grid development, and how to ensure confidentiality of information flows to ensure end-user trust? Another issue is to develop new interpretations of the role of customers, as well as the market entry of completely new actors and roles that lead to new interactions and innovative value chains in the energy system. All in all, the challenge is thus to understand which features of the interaction between end-users and energy market structures contribute to end user engagement and smart energy behaviour.

A $9^{\text {th }}$ key challenge relates to up-scaling and replicating pilot projects involving a diverse end-user group. Although significant experience exists with pilot projects, little experience has been gained in larger scale roll-outs. Findings from pilot projects - often targeting specific end-user groups (e.g. "early adopters") - can not a priori be transferred to the case of larger scale roll-outs dealing with a much more diverse audience involving amongst others relatively "indifferent" end-user groups. The challenge is thus to understand which issues hamper and/or facilitate up-scaling or replication of smart energy projects.

\section{Conclusion}

Our review shows that an end-user centred approach in smart grid projects is needed. Such an approach should address both conscious (e.g. buying smart appliances) and habitual (e.g. energy related practices) forms of behaviour and the enablers and barriers that may apply. Much is known about the possible enablers and barriers of smart energy behaviour (Table 1). However, as all end users are different, enduser engagement strategies should differentiate to understand which enablers and barriers are of specific relevance for the targeted end-user group. Also, an extensive list of reported success factors for end-user engagement was given (Table 2 and Table 3). We stress that this list is not to be interpreted as a blue print, but rather as an overview of factors that need to be considered when designing or evaluating an 
end-user engagement strategy. A number of key challenges for future research have been formulated that may provide future directions for better linking smart end-users, smart energy providers and smart grids in a better balanced and more sustainable electricity system.

\section{References}

[1] Report on state-of-the-art and theoretical framework for end-user behaviour and market roles (S3C Deliverable 1.1. available at http://www. s3c-project.eu/Deliverables.html, 2013)

[2] H. Aarts, B. Verplanken, A. van Knippenberg, Predicting behaviour from actions in the past: repeated decision making or a matter of habit? J. Appl. Soc. Psychol. 28, 1355-1374 (1998)

[3] N. Prüggler, Economic Potential of Demand Response at Household level-Are Central-European Market Conditions Sufficient?, Energy Policy 60, 487-498 (2013)

[4] G. Verbong, S. Beemsterboer, F. Sengers, Smart grids or smart users? Involving users in developing a low carbon electricity economy. Energy Policy 52, 117-125 (2013)

[5] C. Bartusch, F. Wallin, M. Odlare, I. Vassileva, and L. Wester, Introducing a Demand-based Electricity Distribution Tariff in the Residential Sector: Demand Response and Customer Perception. Energy Policy 39, 5008-5025 (2011)

[6] Smart Grid projects in Europe: lessons learned and current developments (JRC, Institute for Energy, Petten, 2011)

[7] 2013 State of the Consumer Report (SGCC, http://smartgridcc.org/, 2013)

[8] Achieving energy efficiency through behaviour change: what does it take? (EEA Rep. No. 5/2013, European Environment Agency, Copenhagen, 2013)

[9] E.J. McCarthy, Basic marketing: a managerial approach. (Richard D. Irwin, Homewood, 1960)

[10] E. St. E.. Lewis, Financial Advertising (AIDA Model) (Garlard Publishing, New York \& London, 1985)

[11] R. B.Cialdini, Influence - The Psychology of Persuasion (William Morrow and Company, New York, 1984)

[12] A Framework for Pro-Environmental Behaviours (DEFRA, London, 2011)

[13] Big Pocket Guide to using social marketing for behaviour change (NSMC, London, 2011)

[14] K. Ehrhardt-Martinez, Advanced Metering Initiatives and Residential Feedback Programs: a meta-review for household electricity savings opportunities (ACEEE, 2010)

[15] S. Darby, The effectiveness of feedback on energy consumption. A review for DEFRA of the literature on metering, billing and direct displays (Environmental Change Institute, Oxford, 2006)

[16] P.E. Lewis, C. Dromacque, S. Brennan, J. Stromback, D. Kennedy, Empower Demand 2: Energy Efficiency through Information and Communication Technology: Best Practice Examples and Guidance (VaasaETT, Helsinki, 2012)

[17] The eFlex Project (Dong Energy, Virum, Denmark, 2012)

[18] S. Breukers, R.M. Mourik, The end-users as starting point for designing dynamic pricing approaches to change household energy consumption behaviours, Report for Netbeheer Nederland, (DuneWorks, Eindhoven, 2013)

[19] Interaction schemes for successful energy demand side management. Building blocks for a practicable and conceptual framework (Deliverable 5 of the Changing Behaviour project, www . energychange.info, 2009)

[20] J. Rotmans, Societal Innovation: between dream and reality lies complexity (Inaugural Adress, Erasmus University Rotterdam, 2005) 